\title{
Leprosy and the serodiagnostic test for tuberculosis
}

\author{
J. G. CRUICKSHANK ${ }^{1}$ AND B. P. B. ELLIS \\ From the Department of Medical Microbiology, University of Rhodesia, Salisbury, Rhodesia
}

SUMMARY Sera from patients with leprosy agglutinated killed H37Rv Mycobacterium tuberculosis to varying degrees. Higher titres were found in association with active disease but there was no $\vec{\omega}$ difference between patients at the lepromatous or at the tuberculoid ends of the clinical scale. A sharp rise in titre occurred during the active phase of an episode of erythema nodosum leprosum.

While recent studies demonstrate that leprosy bacilli share some common antigens with the other mycobacteria, the relationship between Mycobacterium leprae and $M$. tuberculosis is still uncertain (Stanford et al., 1975). In the course of an investigation into the value of a serodiagnostic test for tuberculosis (Nicholls, 1975) in Central African subjects, sera from patients with leprosy were also examined to determine whether any reaction would occur with $M$. tuberculosis antigen and, if so, what use might be made clinically of the result.

\section{Methods}

The patients were all Rhodesian Africans. The majority were attending, as outpatients, the Leprosy Unit at Harare Central Hospital, Salisbury; a smaller group were residents at the Mtemwa Welfare Hospital for mutilated and destitute patients who were quite unable to fend for themselves. Those attending the Leprosy Unit were assessed on clinical, bacteriological, and histopathological criteria and were classified as to type of disease (Ridley and Jopling, 1966) and into one of the following categories of activity-inactive, healing, active, or in reaction. The Mtemwa cases were all of long standing and were not subdivided into types as many of their records had been lost. All had been on treatment for many years and were regularly examined for signs of activity.

All patients were clinically free from tuberculosis.

Sera were stored at $-20^{\circ} \mathrm{C}$ without preservative.

Antigen was prepared by Dr Nicholls, of the Midhurst Medical Research Institute, from $M$. hominis as previously described (Nicholls, 1975),

'Present address: Public Health Laboratory, Church Lane, Heavitree, Exeter EX2 5AD

Received for publication 7 February 1977 except that a virulent strain (H37Rv) was used for $\infty$ this batch.

The agglutination tests were performed by the modified Widal technique as used by Nicholls et al. (1975).

\section{Results}

Table 1 presents the results in relation to the degree of activity and, in the case of the Leprosy Unit only, the clinical varieties of the disease. The Mtemwa cases were all regarded as inactive, and this was confirmed on clinical grounds at the time of bleeding.

All sera were screened at a dilution of 1 in 50 and those positive titrated out to 1 in 1250 .

In Table 2 the results are analysed according to whether the titre was above or below 1 in 500. This dividing line was chosen because studies on normal African individuals showed that a high proportiono had titres of 1 in 250 (unpublished data). The resultshorizontally summarise the position with regard to 3 . the degree of activity of the cases while vertically they refer to the clinicopathological type of the disease.

One case of lepromatous leprosy was followed ato weekly intervals over a 10-week period during which? he developed and recovered from a typical attack of erythema nodosum leprosum. The titres are presented graphically in the Figure.

\section{Discussion}

Almeida (1970) surveyed the literature on the serology of leprosy. Much of the work involved the use of antigens from $M$. tuberculosis, and complement fixing, precipitating, and fluorescent antibodies were found regularly in lepromatous patients and less often in tuberculoid ones. Indirect haemagglutination tests using tuberculin sensitised sheep cells gave्फ similar results (Levine, 1951), and Axelsen et al: 
Table 1 Results of agglutination tests in patients by degrees of activity and type of disease (Leprosy Unit and Mtemwa cases)

\begin{tabular}{|c|c|c|c|c|c|c|}
\hline \multirow[t]{2}{*}{ Activity of disease } & \multicolumn{5}{|c|}{ Numbers of patients at each titre } & \multirow[t]{2}{*}{ Total patients } \\
\hline & $<1 / 125$ & $1 / 125$ & $1 / 250$ & $1 / 500$ & $\$ 1 / 1250$ & \\
\hline \multicolumn{7}{|l|}{ Inactive } \\
\hline TT & 3 & 3 & - & 1 & - & 7 \\
\hline BT & 1 & 2 & - & - & 一 & 3 \\
\hline $\mathbf{L} \mathbf{L}$ & 1 & 4 & 一 & - & 1 & 6 \\
\hline Mtemwa & 30 & 31 & 5 & 8 & 3 & 77 \\
\hline \multicolumn{7}{|l|}{ Healing } \\
\hline TT & 1 & 2 & 1 & 2 & 1 & 7 \\
\hline BT & - & 3 & - & 3 & - & 6 \\
\hline BB & - & 1 & - & - & - & 1 \\
\hline BL & - & 1 & - & 1 & - & 2 \\
\hline LL & - & 2 & 3 & 5 & - & 10 \\
\hline \multicolumn{7}{|l|}{ Active } \\
\hline TT & - & 4 & 0 & 6 & 5 & 15 \\
\hline BT & 4 & 1 & - & 5 & 8 & 18 \\
\hline BB & - & 1 & - & - & 3 & 4 \\
\hline BL & - & 2 & 1 & 2 & 1 & 6 \\
\hline$\widehat{L L}$ & 3 & 1 & 2 & 12 & 36 & 54 \\
\hline \multicolumn{7}{|l|}{ In reaction } \\
\hline BB & - & - & - & - & 1 & 1 \\
\hline$\overline{B L}$ & - & - & - & 2 & 2 & 4 \\
\hline $\overrightarrow{\mathbf{L}}$ & - & - & - & 1 & 5 & 6 \\
\hline Total & 43 & 58 & 12 & 48 & 66 & 227 \\
\hline
\end{tabular}

TT = tuberculoid; $\mathrm{BT}=$ borderline tuberculoid $; \mathrm{BB}=$ borderline; $\mathrm{BL}=$ borderline lepromatous $; \mathrm{LL}=$ lepromatous.

Table 2 Summary of cases with high or low titres in relation to type of disease and degree of activity

\begin{tabular}{|c|c|c|c|c|c|c|c|c|c|c|c|c|c|c|c|c|}
\hline & \multicolumn{7}{|c|}{ Titre $₹ 1 / 250$} & \multicolumn{7}{|c|}{ Titre $>1 / 500$} & \multirow[t]{2}{*}{$\%<1 / 250$} & \multirow[t]{2}{*}{$\%>1 / 500$} \\
\hline & $T T$ & $B T$ & $B B$ & $B L$ & $L L$ & Mte & n. Total & $T T$ & $B T$ & $B B$ & $B L$ & $L L$ & Mtem. & Total & & \\
\hline $\begin{array}{l}\text { Inactive } \\
\text { Healing } \\
\text { Active } \\
\text { In reaction }\end{array}$ & $\begin{array}{r}6 \\
4 \\
4 \\
-\end{array}$ & $\begin{array}{r}3 \\
3 \\
5 \\
-\end{array}$ & $\begin{array}{l}-1 \\
1 \\
-\end{array}$ & $\begin{array}{r}-2 \\
3 \\
-\end{array}$ & $\begin{array}{r}5 \\
5 \\
6 \\
-\end{array}$ & $\frac{66}{-}$ & $\begin{array}{l}80 \\
15 \\
19 \\
0\end{array}$ & $\begin{array}{r}1 \\
3 \\
11 \\
-\end{array}$ & $\begin{array}{r}-3 \\
13 \\
-\end{array}$ & $\begin{array}{l}- \\
3 \\
1\end{array}$ & $\begin{array}{l}\bar{Z} \\
3 \\
4\end{array}$ & $\begin{array}{r}1 \\
5 \\
48 \\
6\end{array}$ & $\frac{11}{-}$ & $\begin{array}{l}13 \\
11 \\
78 \\
11\end{array}$ & $\begin{array}{r}86 \\
58 \\
20 \\
0\end{array}$ & $\begin{array}{r}14 \\
42 \\
80 \\
100\end{array}$ \\
\hline $\begin{array}{l}\text { Total } \\
\% \text { of total }\end{array}$ & $\begin{array}{l}14 \\
49\end{array}$ & $\begin{array}{l}11 \\
41\end{array}$ & $\begin{array}{r}2 \\
34\end{array}$ & $\begin{array}{r}5 \\
42\end{array}$ & $\begin{array}{l}16 \\
22\end{array}$ & $\begin{array}{l}66 \\
86\end{array}$ & & $\begin{array}{l}15 \\
51\end{array}$ & $\begin{array}{l}16 \\
59\end{array}$ & $\begin{array}{r}4 \\
67\end{array}$ & $\begin{array}{r}7 \\
58\end{array}$ & $\begin{array}{l}60 \\
78\end{array}$ & $\begin{array}{l}11 \\
14\end{array}$ & & & \\
\hline
\end{tabular}

(1974) demonstrated agglutination with BCG though he doubted the specificity of the antibodies. Both in the indirect haemagglutination and in the complement fixing tests untreated cases gave higher titres on the whole than the treated. Recent studies show that though the sera of many patients with lepromatous leprosy react with antigens derived from a wide range of mycobacterial species (Abe, 1970; Navalkar, 1971), M. leprae seems to be missing both the antigens characteristic of the slow and of the fast growing groups of mycobacteria (Stanford et al., 1975).

In this test any correlation there is between titre and clinical state is with the degree of activity rather than with the type of disease. Only at the lepromatous end of the leprosy spectrum is the proportion of cases with higher titres significantly greater than those with lower ones. However, the gradation from the inactive through the active to the more fulminant reactional state is accompanied by a striking shift from low to high titres (whether or not the Mtemwa cases are included). Such findings are like those of Nicholls and Horsfield (1976), who, using the same antigen in tuberculous subjects, found titres of 1 in 125 and over to occur only in active cases. Further, the lack of correlation with the tuberculin test in their series parallels that with the lepromin test in ours which is positive only in the high resistance cases at the tuberculoid end of the spectrum.

Reactional states are generally associated with alterations in the cellular type of immunity but it is apparent that there are also temporary alterations in the level of circulating antibody. 


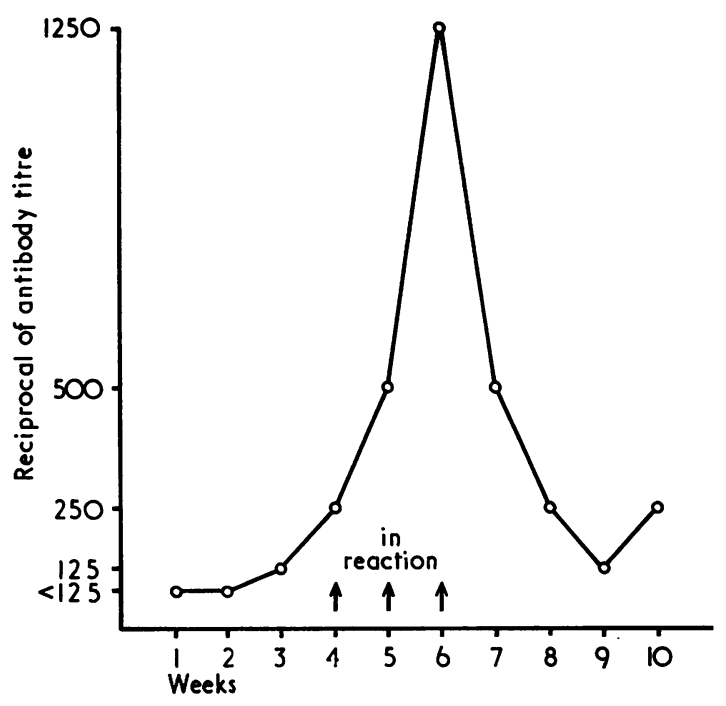

Figure Changes in titre in one patient during a type 2 reaction.

All that can be said at the moment is that agglutinating antibody to mycobacterial antigens reflects to some extent the activity of leprosy but not with the degree of accuracy of more conventional tests (ie, histology, etc). It will be of interest to compare results when cultivated leprosy bacilli become more readily available for use as antigen.

We are grateful to Dr A. Nicholls, of the Midhurst Medical Research Institute, for supplying us with the antigen. The technical expertise of Mrs F. E. Brand and Mrs J. Travers-Drapes and the secretarial assistance of Miss C. Ellis are gratefully acknowledged.

\section{References}

Abe, M. (1970). Studies on the antigenic specificity of Mycobacterium leprae. 1. Demonstration of soluble antigens in leprosy nodules by immunodiffusion. International Journal of Leprosy, 38, 113-125.

Almeida, J. de (1970). Serology in leprosy. Bulletin of the World Health Organization, 42, 673-702.

Axelsen, N. H., Harboe, M., Closs, O., and Godal, T. (1974). BCG antibody profiles in tuberculoid and lepromatous leprosy. Infection and Immunity, 9, 952958.

Levine, M. (1951). Hemagglutination of tuberculin sensitized sheep cells in Hansen's disease (leprosy). Proceedings of the Society for Experimental Biology and Medicine, 76, 171-173.

Navalkar, R. G. (1971). Immunologic analysis of Mycobacterium leprae antigens by means of diffusion-in-gel methods. International Journal of Leprosy. 39, 105-112.

Nicholls, A. C. (1975). A serodiagnostic test for tuberculosis. Journal of Clinical Pathology, 28, 850-853.

Nicholls, A. C. and Horsfield, K. (1976). Serological diagnosis of tuberculosis: a report of 12 months' clinical experience. Thorax, 31, 289-293.

Nicholls, A. C., Pease, P. E., and Green, I. D. (1975). Agglutinin response to bacterial infection in acute exacerbations of chronic bronchitis. Journal of Clinical Pathology, 28, 279-283.

Ridley, D. S. and Jopling, W. H. (1966). Classification of leprosy according to immunity. A five group system. International Journal of Leprosy, 34, 255-273.

Stanford, J. L., Rook, G. A. W., Convit, J., Godal, T., Kronvall, G., Rees, R. J. W., and Walsh, G. P. (1975). Preliminary taxonomic studies on the leprosy bacillus. British Journal of Experimental Pathology, 56, 579-585. 